\title{
Epoxyeicosatrienoic acid Metabolism Preeclampsia
}

\section{Preeklampside Epoksieikozatrienoilk asit Metabolizması}

\author{
Ismail Saria ${ }^{a}$ Hatice Pinarbasib ${ }^{\mathrm{b}}$, Caglar Yildizc
}

${ }^{a}$ Department of Medical Biochemistry, School of Medicine, Niğde Ömer Halisdemir University, Niğde, Turkey

${ }^{\mathrm{b}}$ Department of Biochemistry, School of Medicine, Beykent University, İstanbul, Turkey;

Department of Gynecology and Obstetrics, School of Medicine, Cumhuriyet University, Sivas, Turkey

Corresponding author: Prof. Dr. Hatice Pinarbaşi, Department of Biochemistry, School of Medicine, Beykent University, 34550 , İstanbul, Turkey

E-mail: hpinar2658@gmail.com

Received/Accepted: June 26, 2018 / December 28, 2018

Conflict of interest: There is not a conflict of interest.

\begin{abstract}
SUMMARY
Objective: Preeclampsia (PE) is a disease that characterized by hypertension and proteinuria during pregnancy. Epoxyeicosatrienoic acids (EETs) are arachidonic acid metabolites which have vasodilatator, anti-inflammatory and profibrinolytic effects. Soluble epoxide hydrolase (sEH; EC 3.3.3.2) catalyses the degradation of EETs to their inactive diols (DHETs). Low circulating levels of EETs may be related to high blood pressure in preeclampsia. The aim of this study is to determine the level of 11,12-DHETs, a representative metabolite of sEH-mediated metabolism of EET, in preeclamptic patients.
\end{abstract}

Method: 11,12-DHET levels were measured by ELISA in plasma samples of 75 PE patients and 75 normotensive pregnant women as controls.

Results: It was found that lasma 11,12-DHET levels of PE patients was significantly increased compared to the control group $(\mathrm{p}<0.05)$.

Conclusions: These results and our previous findings suggest that high sEH activities in PE patients may cause to produce more 11,12-DHETs in PE. sEH enzyme with high catalytic activity may play a role in the pathogenesis of PE by contributing to the reduction of vasodilatator, anti-hypertensive and anti-inflammatory effects of EETs by rapid degradation of these molecules.

Keywords: Dihydroxy-eicosatrienoic acid, Epoxyeicosatrienoic acid, Preeclampsia, Soluble epoxide hydrolase

\section{ÖZET}

Amaç: Preeklampsi (PE) hamilelik sırasında hipertansiyon ve proteinüri ile karakterize bir hastalıktır. Epoksieikozatrienoik asitler (EET) vazodilatatör, antienflamatuar ve profibrinolitik etkiye sahip araşidonik asit metabolitleridir. Çözünür epoksit hidrolaz (çEH EC 3.3.3.2) EET' lerin inaktif diollerine (DHET' ler) yıkımını katalizler. EET' lerin düşük dolaşım düzeyleri preekalampsideki yüksek kan basıncıyla ilişkili olabilir. Bu çalışmanın amacı preeklampsi hastalarında EET' lerin çEH aracılı metabolizmasının temsili bir metaboliti olan 11,12-DHET düzeylerinini belirlenmesidir.

Yöntem: 75 PE hastası ve control grubu olarak 75 normotansif gebe kadının plazma örnkelerinde 11,12-DHET düzeyleri ELISA yöntemi ile ölçüldü.

Bulgular: PE hastalarının plazma 11,12-DHET düzeylerinin control grubuna kıyasla analmalı olarak yükseldiği saptand1.

Sonuç: Bu sonuçlar ve daha önceki bulgularımız PE hastalarında yüksek çEH aktivitesinin daha fazla 11,12-DHET üretimine neden olduğuna işaret etmektedir. Yüksek katalitik aktiviteli çEH enzimi, EET’ lerin hızlı yıkımı yoluyla bu moleküllerin vazodilatatör, antihipertansif, antienflamatuar etkilerinin azalmasına katkı sağlayarak PE patogenizinde bir rol oynuyor olabilir.

Anahtar sözcükler: Dihidroksi-ekzoatrienoik asit, Epoksieikozatrienoik asit, Preeklampsi, Çözünür epoksit hidrolaz 


\section{INTRODUCTION}

Preeclampsia is a pregnancy specific multi-system syndrome characterized by the new onset of hypertension and proteinuria during the second half of pregnancy ${ }^{1}$. It is the leading cause of maternal and fetal mortality and morbidity affecting 3-5\% of all pregnancies ${ }^{2,3}$. Evidence is accumulating that women with history of PE may have increased risk of cardiovascular diseases (CVD) later in life ${ }^{4-6}$. Although the pathophysiological mechanism of PE is unclear, a substantial amount of evidence indicates that immunological alterations, systemic inflammation, endothelial dysfunction and genetic factors contribute to the pathogenesis of the disease $^{7}$. Clinical manifestations such as hypertension and proteinuria indicate the endothelium as the target of the disease ${ }^{8}$ and it is believed that endothelial dysfunction is a hallmark of $\mathrm{PE}^{9,10}$.

Vascular endothelium releases vasodilatators such as nitric oxide (NO), prostacyclin and endothelium derived hyperpolarizing factors (EDHF) and also vasoconstrictors to regulate vascular tone ${ }^{11-13}$. Endothelial dysfunction, characterized by a disrupted balance in the production and/or degradation between these molecules resulting in higher concentration of vasoconstrictors is a major predisposing factor for $\mathrm{PE}^{14-15}$. Endothelium-dependent vasodilatation mediated by other than prostacyclin and NO has been attributed to EDHF that includes epoxyeicosatrienoic acids (EETs), hydrogene peroxide $\left(\mathrm{H}_{2} \mathrm{O}_{2}\right)$, potassium and probably other factors ${ }^{16}$. Published data provide convincing evidence for EETs action as EDHFs in arteries from a variety of species including humans ${ }^{17-24}$. EETs are synthesized from arachidonic acid (AA) by CYP 450 epoxigenases localized in endothelial and vascular smooth muscle cells. CYP2C and CYP2J families of CYP epoxygenases convert AA to four biologically active EETs (5, 6-EET, 8, 9-EET, 11, 12-EET, and 14, 15-EET) that have vasoprotective, antihypertensive, antiimflammatory and profibrinolytic effects ${ }^{25-27}$. In addition to circulating levels of EETs, they are formed in the placenta, trophoblast, amnion, chorion, decidua, and myometrium of the gravid uterus $^{28-30}$. Growing evidence suggest that EETs' contribute to the physiological response to normal pregnancy and the pathophysiology of pregnancy induced hypertension. Jiang et al. reported that EETs may modulate systemic and fetoplacental hemodynamics in normal and preeclamptic pregnancies. Decreased renal EET generation may be associated with the hypertension in preeclampsia $^{31}$. Catella et al. showed an increase in the biosynthesis of EETs in human pregnancy and a further increment in pregnancy induced hypertension $^{32}$. Zhou et al. suggested that EET synthesis in the kidney was elevated during pregnancy and EETs may contribute to the control of blood pressure during pregnancy. Inhibition of EET producing enzymes (CYP2C11, 2C23, and CYP2J2) by PPOH (an epoxygenase inhibitor) caused hypertension in pregnant rats ${ }^{33}$.

The EETs are hydrated enzymatically to the corresponding dihydroxy-eicosatrienoic acids (DHETs) by epoxide hydrolases. DHETs are less active than EETs and more readily excreted. The reaction catalysed by soluble epoxide hydrolase $(\mathrm{sEH}$; EC 3.3.3.2) is the main pathway in the metabolism of EETs, inhibition of sEH prevents EET hydrolysis and prolongs their biological activities $^{34}$. Our previous study including $260 \mathrm{PE}$ patients and 260 healthy pregnant women revealed that women having more active form (K55R) of sEH were more susceptible to develop PE suggesting that decreased bioavailability of EETs due to the higher degradation rate may play a role in development of $\mathrm{PE}^{35}$. In the present study, we investigated the association between plasma levels of 11, 12 DHET (an EET metabolite) and PE.

\section{MATERIAL AND METHODS}

Study population: This study included 75 pregnant women with PE and 75 normotensive controls that 20 or more week pregnant without cardiovascular diseases and diabetes. PE was defined as the new onset of hypertension (systolic blood pressure $\geq 140 \mathrm{mmHg}$ or diastolic blood pressure $\geq 90 \mathrm{mmHg}$ ) and either proteinuria (Proteinuria $\geq 0.3 \mathrm{~g}$. in a 24 -hour urine specimen or protein: creatinine ratio $\geq 0.3$ ) or end-organ dysfunction (platelet count $<100,000 /$ microliter, serum creatinine $>1.1 \mathrm{mg} / \mathrm{dL}$ or doubling of the serum creatinine, elevated serum transaminases to twice normal concentration) after 20 weeks of gestation ${ }^{36}$. Pregnant women with baseline hypertension, diabetes, cardiovascular diseases, proteinuria, or renal diseases were excluded from the study. Plasma samples used in this study are blood samples taken from the study group of the previous study, which has been approved by Ethical Committee of Cumhuriyet University in Sivas, Turkey (The Decision Number; 201001/09). Informed consent was obtained from all patients and the controls. This work was supported by the Scientific Research Project Fund of Cumhuriyet University (grant number T-551). 
Blood Sampling and Plasma 11, 12 DHET Assay: Blood samples of PE patients and the controls were collected into sitrat containing tubes. The blood samples were centrifuged at $1900 \mathrm{~g}$ for $10 \mathrm{~min}$ at $4{ }^{\circ} \mathrm{C}$. Plasma samples were stored at $-20^{\circ} \mathrm{C}$ until analysed. 11,12 DHET level in plasma was measured using ELISA kit (Eagle Biosciences, Inc.) according to manufacturer's instructions. The results were expressed as nM 11, 12 DHET in plasma.

\section{RESULTS}

The characteristics of the study population were presented Table 1. Mean systolic and diastolic blood pressures were significantly different between patients and controls $(p<0.05)$, although no statistically significant difference was observed in terms of mean age, gravidity and parity $(\mathrm{p}>0.05)$.

Table 1. Demographic features of subject

\begin{tabular}{|c|c|c|c|}
\hline & Patient $(\mathrm{N}=75)$ & Control (N=75) & $p$ \\
\hline $\operatorname{Age} \pm \mathrm{SD}\left(\bar{X}_{ \pm} \mathbf{S}\right)$ & $28.6 \pm 7.1$ & $28.1 \pm 6.0$ & 0.5900 \\
\hline $\operatorname{Gravida}\left(\bar{X}_{ \pm} \mathbf{S}\right)$ & $2.4 \pm 1.8$ & $2.1 \pm 1.9$ & 0.765 \\
\hline $\operatorname{Parity}(\bar{X} \pm \mathbf{S})$ & $1.4 \pm 1.4$ & $1.2 \pm 0.8$ & 0.480 \\
\hline $\mathbf{S B P}\left(\mathbf{m m H g} ; \bar{X}_{ \pm} \mathbf{S}\right)$ & $147.4 \pm 10.1$ & $116.8 \pm 9.1$ & $0.0001 *$ \\
\hline $\operatorname{DBP}\left(\mathbf{m m H g} ; \bar{X}_{ \pm} \mathbf{S}\right)$ & $98.7 \pm 9.4$ & $71.4 \pm 7.6$ & $0.0001 *$ \\
\hline
\end{tabular}

*p<0.05: statistically significant; S: standard deviation; $\bar{X}$ : Mean; SBP: (systolic blood pressure ); DBP (diastolic blood pressure).

As can be seen in Table 2 plasma 11,12 DHET levels in PE patients were significantly higher than controls.

Table 2. Plasma11,12 DHET levels in patients and controls.

\begin{tabular}{|c|c|c|c|}
\hline & $\begin{array}{c}\text { Patient(n=75) Median } \\
\text { (min-max) }\end{array}$ & $\begin{array}{c}\text { Control (n=75) Median } \\
\text { (min-max) }\end{array}$ & $p$ \\
\hline 11,12-DHET (nM) & $190,2(8,6-58031,3)$ & $99,7(14,4-2692,5)$ & $0,001 *$ \\
\hline
\end{tabular}




\section{DISCUSSION}

EETs are CYP 450 metabolites of AA that have vasodilatatory, antihypertensive, antiinflamatory properties. It is well established that EETs act as an endothelial-derived hyperpolarizing factor. Recent evidence suggests an important role for EETs in the development and progression of some metabolic diseases. A considerable amount of data indicates their roles in cardioprotective mechanisms. EETs are mainly generated in the liver, kidney and vascular endothelium ${ }^{5}$. In addition to circulating levels of EETs, they are formed in the placenta, trophoblast, amnion, chorion, decidua, and myometrium of the gravid uterus ${ }^{28-30}$. Therefore in recent years their contribution to physiological response to normal pregnancy and the pathophysiology of pregnancy induced hypertension is pointed out more extensively. EETs are mostly hydrolyzed by $\mathrm{sEH}$ into DHETs, which circulate in the blood and are excreted in the urine ${ }^{4}$. Here we investigated the plasma levels of EET metabolite, 11,12 DHET, in preeclampsia patients and healthy pregnant women. We found about 2 fold higher levels of blood 11,12 DHET in preeclamptic women than in healthy pregnant controls. Catella et al. ${ }^{32}$ found increased urinary excretion of 11,12 DHET in healthy pregnant women compared with nonpregnant female controls and even further increase in patients with pregnancy induced hypertension. Our results agree with theirs that we found higher plasma 11,12 DHET levels in preeclampsia patients than normotensive pregnant women.

Jiang et al. $^{31}$ found increased plasma levels of EETs in both preeclamptic and normotensive pregnancy compared to nonpregnant women and reduced urinary excretion of EETs in the form of DHETs in preeclamptic than normotensive pregnancy. But we found higher plasma 11,12 DHET levels in preeclamptic women than normotensive pregnants in our study that may reflect the systemic rather than intrarenal levels of EETs and also 11,12 DHETs. In our view this difference is generated by using urine for measurement of 11,12 DHET in their study. Because intrarenal rather than systemic EETs contribute to the level of urinary DHETs ${ }^{31}$ and DHETs could be subject to tubular uptake and secretion with the kidney ${ }^{32}$.

From our results, one can conclude that DHET levels increase in plasma as a result of increased plasma EET levels in preeclampsia. Because several studies reported enhanced EET formation in human pregnancy and a further increase in pregnancy induced hypertension ${ }^{31,32}$. However we bring another point of view to explain the results of the present study that increased sEH activity may be responsible for the elevated plasma 11,12 DHETs in preeclampsia compared to normotensive pregnancy. sEH is the enzyme that converts EETs hydrolytically to DHETs. DHETs are generally thought to be inactivation products of EETs ${ }^{37,38}$. At least six human sEH variants exist in the human population and that at least four of these may influence sEH-mediated metabolism of endogenous epoxide substrates in vivo. K55R polymorphism results in higher enzyme activity ${ }^{39}$ and rapid degradation of EETs by this variant of $\mathrm{sEH}$ can cause the higher blood 11,12 DHET levels in PE. An association was reported between K55R polymorphism and hypertension, stroke ${ }^{40}$ and $\mathrm{CVD}^{41}$. Minuz et al. ${ }^{42}$ found reduced ratio of plasma EETs: DHETs in renovascular disease and essential hypertension patients compared to control subjects. They suggest that this reduction may reflect increased sEH activity that will reduce EET levels and, thereby, decrease antipressor activity in renovascular disease and essential hypertension. Because the PE and CVD share many risk factors and pathophysiological features ${ }^{43}$ and EETs contribute to the physiological response to normal pregnancy and the pathophysiology of pregnancyinduced hypertension, we think that individual differences in EET catabolism rate may be a susceptibility factor for PE. Moreover in our previous study we reported for the first time that increased $\mathrm{sEH}$ activity caused by K55R polymorphism and /or the promotor hypomethylation of the gene encoding $\mathrm{sEH}$ (EPHX2) was significantly associated with $\mathrm{PE}^{35}$. These results together with the results of our previous study lead us to conclude that increased activity of $\mathrm{sEH}$ may result in increased plasma 11,12 DHET levels in PE and rapid degradation of EETs due to attenuation of beneficial effects of these molecules (anti-inflammatory, vasoprotective and antihypertensive) in pregnancy may play a role in development of the disease. Further epidemiological and mechanistic studies are needed to understand the effect of EET metabolism on the development of PE.

\section{REFERENCES}

1. Choudhury M, Friedman JE. Epigenetics and microRNAs in preeclampsia. Clinical and experimental hypertension 2012; 34 : $334-41$. 
2. Redman CW, Sargent IL. Latest advances in understanding preeclampsia. Science 2005; 308: 1592-4.

3. Sibai B, Dekker G, Kupferminc M. Preeclampsia. Lancet. 2005; 365: 785-99.

4. Zoet GA, Koster MP, Velthuis BK, de Groot CJM, Maas AHEM, Fauser BCJM, Franx A, van Rijna BB. Determinants of future cardiovascular health in women with a history of preeclampsia. Maturitas 2015; 82: 153-61.

5. Gongora MC, Wenger NK. Cardiovascular complications of pregnancy. International journal of molecular sciences 2015; 16: 23905-28.

6. Lee G, Tubby J. Preeclampsia and the risk of cardiovascular disease later in life-A review of the evidence. Midwifery 2015; 31: 1127-34.

7. Wang A, Rana S, Karumanchi SA. Preeclampsia: the role of angiogenic factors in its pathogenesis. Physiology 2009; 24: 147-58.

8. Hermes W, Van Kesteren F, De Groot CJ. Preeclampsia and cardiovascular risk. Minerva ginecologica 2012; 64: 28192.

9. VanWijk MJ, Kublickiene K, Boer K, VanBavel E. Vascular function in preeclampsia. Cardiovascular research 2000; 47: 38-48.

10. Gilbert JS, Ryan MJ, LaMarca BB, Sedeek M, Murphy SR, Granger JP. Pathophysiology of hypertension during preeclampsia: linking placental ischemia with endothelial dysfunction. American Journal of Physiology-Heart and Circulatory Physiology 2008: 294; H541H550.

11. Furchgott RF, Zawadzki JV. The obligatory role of endothelial cells in the relaxation of arterial smooth muscle by acetylcholine. Nature 1980; 5789: 373-76.

12. Moncada S, Vane JR. The role of prostacyclin in vascular tissue. Federation proceedings 1979; 38: 66-71.

13. Feletou M, Vanhoutte PM. Endothelium-dependent hyperpolarization of canine coronary smooth muscle. British journal of pharmacology 1988; 93: 51524.
14. Fiona Lyall and Ian A. Greer The vascular endothelium in normal pregnancy and pre-eclampsia. Reviews of Reproduction 1996; 1: 107-116.

15. Sibai B, Dekker G, Kupferminc M. Preeclampsia. Lancet 2005; 365: $\quad 785-$ 799.

16. Yang L, Mäki-Petäjä K, Cheriyan J, McEniery C, Wilkinson IB. The role of epoxyeicosatrienoic acids in the cardiovascular system. British journal of clinical pharmacology 2015; 80: 28-44

17. Fisslthaler B, Popp R, Kiss L, Potente M, Harder DR, Fleming I, Busse R. Cytochrome $\mathrm{P} 450 \quad 2 \mathrm{C}$ is an EDHF synthase in coronary arteries. Nature 1999; 6752: 493-7.

18. Popp R, Fleming I, Busse R. Pulsatile stretch in coronary arteries elicits release of endotheliumderived hyperpolarizing factor: A modulator of arterial compliance. Circ Res 1998; 82:696-703.

19. Archer SL, Gragasin FS, Wu X, Wang S, McMurtry S, Kim DH, Platonov $M$, Koshal A, Hasimoto K, Campbell WB, Falck JR, Michelakis ED. Endotheliumderived hyperpolarizing factor in human internal mammary artery is 11,12epoxyeicosatrienoic acid and causes relaxation by activating smooth muscle BKca channels. Circulation 2003; 107:769-776.

20. Coats P, Johnston F, MacDonald J, McMurray JJV, Hillier C. Endotheliumderived

hyperpolarizing factor: Identification and mechanism of action in human subcutaenous resistance arteries. Circulation 2001; 103: 1702-1708.

21. Miura H, Wachtel RE, Liu Y, Loberiza J, F. R, Saito T, Miura M, Gutterman DD. Flow-induced dilation of human coronary arterioles: Important role of $\mathrm{Ca} 2+-$ activated K+ channels. Circulation 2001; 103:1992-1998.

22. Campbell WB, Gebremedhin D, Pratt PF, Harder DR. Identification of epoxyeicosatrienoic acids as endotheliumderived hyperpolarizing factors. Circ Res 1996; 78: 415-423.

23. Huang A, Sun D, Jacobson A, Carroll MA, Falck JR, Kaley G. Epoxyeicosatrienoic acids are released to 
mediate shear stress-dependent hyperpolarization of arteriolar smooth muscle. Circ Res 2005; 96: 376-383.

24. Gauthier KM, Edwards EM, Falck JR, Reddy DS, Campbell WB. 14,15Epoxyeicosatrienoic acid represents a transferable endothelium-dependent relaxing factor in bovine coronary arteries. Hypertension. 2005; 45: 666671.

25. Imig JD. Epoxides and soluble epoxide hydrolase in cardiovascular physiology. Physiological reviews. 2012;92: 101-30.

26. Wang D, DuBois RN. Epoxyeicosatrienoic acids: a doubleedged sword in cardiovascular diseases and cancer. The Journal of clinical investigation 2012; 122: 19-22.

27. Oni-Orisan A, Alsaleh N, Lee CR, Seubert JM. Epoxyeicosatrienoic acids and cardioprotection: the road to translation, Journal of molecular and cellular cardiology 2014; 74: 199-208.

28. Schaefer WR, Werner K, Schweer H, Schneider J, Arbogast E, Zahradnik HP. Cytochrome P450 metabolites of arachidonic acid in human placenta. Prostaglandins 1997; 54: 677-87.

29. Patel L, Sullivan MH, Elder MG. Production of epoxygenase metabolite by human reproductive tissues. Prostaglandins 1989; 38: 615-24.

30. Gerber RT, Anwar MA, Poston L. Enhanced acetylcholine induced relaxation in small mesenteric arteries from pregnant rats: an important role for endothelium-derived hyperpolarizing factor (EDHF). Br J Pharmacol 1998; 125: 455-60.

31. Houli Jiang, John C. McGiff, Cristiano Fava, Gabriella Amen, Elisa Nesta, Giovanni Zanconato, John Quilley, Pietro Minuz. Maternal and Fetal Epoxyeicosatrienoic Acids in Normotensive and Preeclamptic Pregnancies American Journal of Hypertension 2013; 26: 271-278.

32. Catella F, Lawson JA, Fitzgerald DJ, Fitzgerald GA. Endogenous biosynthesis of arachidonic acid epoxides in humans: Increased formation in pregnancy-induced hypertension. Proc. Nati. Acad. Sci 1990; 87: 5893-5897.

33. Zhou Y, Chang HH, Du J, Wang CY, Dong Z, Wang MH. Renal epoxyeicosatrienoic acid synthesis during pregnancy. American Journal of
Physiology-Renal Physiology 2005; 288: 221-226.

34. Spector AA, Fang X, Snyder GD, Weintraub NL. Epoxyeicosatrienoic acids (EETs): metabolism and biochemical function. Progress in Lipid Research 2004; 43: 55-90.

35. Sari I, Pinarbasi H, Pinarbasi E, Yildiz C. Association between the soluble epoxide hydrolase gene and preeclampsia. Hypertens Pregnancy 2017; doi.org/10.1080/10641955.2017.1388390.

36. American College of Obstetricians and Gynecologists. Hypertension in pregnancy. Report of the American college of obstetricians and gynecologists' task force on hypertension in pregnancy. Obstetrics and gynecology 2013; 122: 1122.

37. Roman RJ. P-450 metabolites of arachidonic acid in the control of cardiovascular function. Physiol Rev 2002; 82: 131-85.

38. Zeldin DC. Epoxygenase Pathways of Arachidonic Acid Metabolism J Biol Chem 2001; 276: 36059-62.

39. Przybyla-Zawislak BD, Srivastava PK, Vázquez-Matías J, Mohrenweiser HW, Maxwell JE, Hammock BD, BradburyJA, Enayetallah AE, Zeldin DC, Grant DF. Polymorphisms in Human Soluble Epoxide Hydrolase. Molecular Pharmacology 2003; 64: 482-90.

40. Fava C, Montagnana M, Danese E, Almgr en P, Hedblad B, Engström G, Göran B, Minuz, Pietro M, Olle M. Homozygosity for the EPHX2 K55R polymorphism increases the long-term risk of ischemic stroke in men: a study in Swedes. Pharmacogenetics and genomics 2010; 20: 94-103.

41. Lee CR1, North KE, Bray MS, Fornage M, Seubert JM, Newman JW, Hammock BD, Couper DJ, Heiss G, Zeldin DC. Genetic variation in soluble epoxide hydrolase (EPHX2) and risk of coronary heart disease: The Atherosclerosis Risk in Communities (ARIC) study. Hum. Mol. Genet 2006; 15: 1640-9.

42. Pietro Minuz, Houli Jiang, Cristiano Fava, Lucia

Tacconelli, Marco Turolo, Stefania Patrignani, Alberto Morganti, Alessandro Lechi, McGiff JC. Altered Release of Cytochrome P450 Metabolites of Arachidonic Acid in Renovascular 
Disease Hypertension 2008; 51: 13791385.

43. Staff AC, Dechend R, Pijnenborg R. Learning From the Placenta Acute Atherosis and Vascular Remodeling in Preeclampsia-Novel Aspects for Atherosclerosis and Future Cardiovascular Health. Hypertension 2010; 56: 1026-34. 